\title{
ОСНОВНЫЕ АСПЕКТЫ НАЛОГОВОЙ ПОЛИТИКИ ЕВРОПЕЙСКОГО СОЮЗА
}

Аннотация. Автор рассматривает основные вопросы налогового права и политики Европейского Союза. Рассматриваются правовые основы налоговой политики, компетенция Евросоюза и государств-членов в налоговой сфере. Автор считает, что ключевыми принципами координации налогового администрирования государств-членов в ЕС являются: устранение дискриминачии и двойного налогообложения; предотвращение злоупотреблений налоговыми правами; снижение издержек, связанных с налогообложением доходов в разных налоговых юрисдикциях. Автор отмечает, что именно создание общего рынка ЕС в 60-х годах ХХ века и его трансформация в единый внутренний рынок в начале 90-х годов потребовали создания условий формирования принципов и норм в области налогов и сборов, которые бы обеспечивали реализачию основных свобод: свободное движение товаров, услуг, лии и капитала между государствами-членами ЕС. Согласно праву ЕС эти свободы не должны ограничиваться какими-либо препятствиями, в частности, налогового характера. Соответственно, прочесс координации налоговых системгосударств-членов ЕС был призван, прежде всего, обеспечить единство внутреннего рынка ЕС. Ключевые слова: европейское право, Европейский Союз, налоговое право, координачия, налоговое администрирование, налоговая конкуренция, сотрудничество, фискальный суверенитет, юрисдикция, налоговая сфера. Abstract: The author studies the main issues of tax law and policy of the European Union. The author evaluates the legal fundamentals for the tax policy, the competence of the European Union and the member states in the tax sphere. The author considers that the key principles for the coordination of tax administration of the member states in the EU are: avoiding discrimination and double taxation, prevention of abuse of competence by the tax bodies, lowering the costs regarding taxation in different tax jurisdictions. The author notes, that it is the formation of the common EU market in 1960s and its transformation into the united domestic market in early 1990s required the conditions for the formation of norms and principles in the sphere of taxes and levies, which would guarantee implementation of the basic rights and freedoms: free movement of goods, services, persons and capital among the EU Member States. According to the EU law these freedoms may not be abridged with any obstacles, including those in the sphere of taxation. Accordingly, the coordination process for the tax systems of the EU Member States was aimed first of all at guaranteeing the unity of the domestic market of the EU. Keywords: European law, the European Union, tax law, coordination, tax administration, tax competition, cooperation, fiscal sovereignty, jurisdiction, tax sphere.

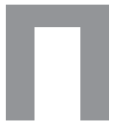
равовое регулирование налогов и сборов в ЕС обусловлено наличием нескольких факторов. Во-первых, можно выделить принципиальное различие между сферами прямого и косвенного налогообложения в ЕС, каждая из которых имеет свою специфику регулирования на наднациональном уровне. Во-вторых, администрирование в сферах прямого и косвенного налогообложения в государствах-членах ЕС регулируется на уровне ЕС, исходя из целей и задач, актуальных для интеграции государств-членов ЕС.

Применительно к первому фактору следует отметить, что если в случае косвенного налогообложения существует гармонизация налоговых систем государств-членов ЕС, то в области прямого налогообложения осуществляется процесс координации. При осуществлении координации налоговых систем Комиссия ЕС издает Сообщения, которые посвящены конкретным проблемам налогообложения, и относящиеся к так называемым нормам «мягкого права». И поскольку «мягкое право» является индикатором правового убеждения, постольку его правовое качество выражается в рамках традиционных, признанных сообществом государств источников права. Зачастую оно может быть использовано для толкования традиционных источников права. Кроме того, его действие обусловлено значением для правоприменения ${ }^{1}$.

\footnotetext{
${ }^{1}$ Shelton (Hrsg) Commitment and Compliance: the Role of NonBinding Norms in the International Legal System, 2000. P.15
} 
Еще в 1967 году была принята Программа Комиссии ЕЭС по гармонизации прямых налогов, в которой определялся следующий перечень задач:

- устранение всех налоговых барьеров для перемещения капитала, единого рынка и расширения инвестиций;

- обеспечение налогового нейтралитета корпоративных операций по реструктуризации и трансграничным слияниям;

- обеспечение условий для реализации принципа равной конкуренции в сфере инвестиций с помощью выравнивания налоговых стимулов и методов исчисления налогов;

- устранение различий между налогами, взимаемыми с активов компаний, инкорпорированных в государствах-членах;

- создание единообразной налоговой базы налога на корпорации и метода исчисления прибыли;

- сближение ставок налога на корпорации государств-членов;

- координация способов проведения налоговых проверок и взимания налогов;

- устранение двойного налогообложения, которое не может быть достигнуто в процессе гармонизации ${ }^{2}$.

Вместе с тем этим инициативам не суждено было сбыться, поскольку государства-члены ЕС неоднократно выражали свою позицию сохранения фискального суверенитета в сфере прямого налогообложения. Таким образом, вместо гармонизации прямого налогообложения в ЕС в настоящее время осуществляется координация налоговых систем государств-членов ЕС, что с одной стороны позволяет сохранить фискальный суверенитет государств, с другой - посредством норм мягкого права воздействовать на формирование налоговых политик государств-членов.

В частности, общая стратегия налоговой политики ЕС содержится в Сообщении Комиссии EC от 23 мая 2001 года о «Налоговой политике в ЕС - приоритеты на будущие годы». В этом сообщении Комиссия ЕС указала, что не существует

\footnotetext{
${ }^{2}$ EEC Fiscal and Fin. Comm., Tax Harmonization in the Common Market (Newmark Report) (July 9, 1962). // Захаров A. C. Налоговое право ЕС. Актуальные проблемы функционирования единой системы. М., 2010
}

необходимости в гармонизации национальных налоговых систем государств-членов ЕС. Право выбирать ту или иную систему налогообложения оставлено за государствами-членами ЕС, при условии соблюдения права ЕС.

Налоговая политика ЕС состоит из системы мер, проводимых не только институтами и органами ЕС, но и государствами-членами в целях гармонизации и координации налогового законодательства государств-членов для устранения налоговых барьеров на внутреннем рынке, обеспечения реализации основных свобод, закрепленных учредительным актом ЕС, недопущения недобросовестной и пагубной налоговой конкуренции, дискриминации на внутреннем рынке, создании норм об избежании двойного налогообложения. Однако в учредительном акте ЕС налоговая политика не определяется в качестве отдельного вида политики ЕС (ст.3 Договора о функционировании $\mathrm{EC})^{3}$. Вместе с тем в учредительном акте ЕС закреплено, что в компетенцию ЕС входит сближение (гармонизация), которое необходимо с целью обеспечить создание или функционирование внутреннего рынка и не допустить искажений конкуренции (ст.113 Договора о функционировании ЕС).

Институты ЕС осуществляют свою деятельность по налоговым вопросам только в том случае, если государство-член ЕС не может эффективно решить возникшие проблемы. По сути проблемы возникают из-за отсутствия должного уровня координации между налоговыми политиками государств-членов ЕС. В Договоре о функционировании ЕС содержится следующее положение: «В отдельных сферах и согласно условиям, предусмотренным Договорами, Союз располагает компетенцией осуществлять деятельность, направленную на поддержку, координацию или дополнение деятельности государств-членов, не подменяя при этом их компетенцию в данных сферах» (ст. 5(2) Договора о функционировании ЕС).

В связи с процессом координации национальных налоговых систем Комиссия ЕС выразила мнение, согласно которому сохранение единогласия в голосовании по налоговым вопросам не способствует данному процессу ${ }^{4}$. Соответственно,

\footnotetext{
${ }^{3} \mathrm{http}: / /$ eulaw.ru/treaties/tfeu

${ }^{4} \mathrm{http}: / /$ ec.europa.eu/prelex/detail_dossier_real.cfm?CL=en\&DosId $=185410$
} 
DOI: $10.7256 / 2226-6305.2014 .2 .11558$

При цитировании этой статьи сноска на dоі обязательна

было предложено заменить такое голосование на голосование посредством квалифицированного большинства, однако государства-члены ЕC не подержали мнение Комиссии по этому вопросу. Таким образом, фискальный суверенитет является не простой декларацией, а выражает реалии функционирования ЕС.

Основными целями координации налоговых систем являются, по мнению Комиссии ЕС, устранение фискальных барьеров, дискриминации и двойного налогообложения на уровне ЕС. Соответственно, основным результатом координации прямого налогообложения должно стать соответствие национальных правовых систем первичному и вторичному праву ЕС (в том числе судебной практике).

Таким образом, в соответствии с правом Сообщества государства-члены вправе формировать системы прямого налогообложения, исходя из собственных целей и задач налоговой политики.

Вместе с тем нормы национальных законодательств, принятие которых обусловлено только местными потребностями приводит к разнообразию подходов государств-членов ЕС в контексте трансграничных правоотношений. Как следствие, физические и юридические лица могут подвергаться двойному налогообложению или нести дополнительные убытки, связанные с различными подходами к налоговому администрированию. В частности, для физических лиц могут возникать препятствия в связи с налогообложением доходов, возникших в других государствах-членах $\mathrm{EC}$, в то время как у компаний могут появляться сложности с инвестированием на территории государств-членов, где они не инкорпорированы ${ }^{5}$.
Эти проблемы не могут быть полностью решены посредством заключения двусторонних договоров между государствами-членами без соответствующего регулирования на уровне EC. Различные препятствия фискального характера, установленные в национальных законодательствах государств-членов, были предметом оспаривания со стороны налогоплательщиков в Суде ЕС, когда этот судебный орган интерпретировал и применял нормы учредительного акта $\mathrm{EC}^{6}$.

Таким образом, ключевыми принципами для координации налогового администрирования государств-членов в ЕС являются:

1. устранение дискриминации и двойного налогообложения;

2. предотвращение злоупотреблений налоговыми правами;

3. снижение издержек, связанных с налогообложением доходов в разных налоговых юрисдикциях.

Таким образом, создание общего рынка ЕC в 60-х годах XX века и его трансформация в единый внутренний рынок в начале 90-х годов потребовали создания условий формирования принципов и норм в области налогов и сборов, которые бы обеспечивали реализацию основных свобод: свободное движение товаров, услуг, лиц и капитала между государствами-членами ЕС. Согласно праву ЕС эти свободы не должны ограничиваться какими-либо препятствиями, в частности, налогового характера. Соответственно, процесс координации налоговых систем государств-членов ЕС призван, прежде всего, обеспечить единство внутреннего рынка ЕC.

\section{Библиография:}

1. Shelton (Hrsg) Commitment and Compliance: the Role of Non-Binding Norms in the International Legal System, 2000. P.15

2. EEC Fiscal and Fin. Comm., Tax Harmonization in the Common Market (Newmark Report) (July 9, 1962). // Захаров А. С. Налоговое право ЕС. Актуальные проблемы функционирования единой системы. M., 2010

3. http://eulaw.ru/treaties/tfeu

4. http://ec.europa.eu/prelex/detail_dossier_real.cfm?CL=en\&DosId $=185410$ ${ }^{5}$ Communication from the Commission to the Council. "Towards
an Internal Market without tax obstacles", COM [2001]582
${ }^{6}$ Case C-106/91 Ramrath [1992] ECR I-3351; Case C-48/75 Royer [1976] ECR 497; Case C-152/03 Ritter [2006] ECR I-1711 и др. 
5. Communication from the Commission to the Council. "Towards an Internal Market without tax obstacles", COM [2001]582

6. Case C-106/91 Ramrath [1992] ECR I-3351; Case C-48/75 Royer [1976] ECR 497; Case C-152/03 Ritter [2006] ECR I-1711 и др.

7. Гидирим В.А. Принцип резидентства корпораций в международном налоговом праве // NB: Международное право. - 2013. - № 1. - C.123-170. DOI: 10.7256/2306-9899.2013.1.427. URL: http://enotabene.ru/wl/article_427.html

8. Постникова Е.В. Правовое регулирование признания профессиональных квалификаций в сфере предоставления услуг в Европейском Союзе // NB: Международное право. - 2013. - № 1. - С.75-122. DOI: 10.7256/2306-9899.2013.1.592. URL: http://e-notabene.ru/wl/article_592.html

9. Бабин Б.В. Programmatic Regulation in the Modern International Law // NB: Международное право. 2013. - № 3. - C.1-35. DOI: 10.7256/2306-9899.2013.3.9302. URL: http://e-notabene.ru/wl/article_9302.html

10. А.В. Гришин. Евро как национальная валюта третьих стран и территорий с особым статусом // Право и политика. - 2009. - № 8.

11. О.В. Гусева. Европейский Союз: правовое регулирование прямых иностранных инвестиций. // Политика и Общество. - 2009. - № 6.

12. Иншакова А.О.. Унифицированное правовое поле инновационного экономического развития и нанотехнологий ЕС // Право и политика. - 2013. - № 7. - С. 104-107. DOI: 10.7256/1811-9018.2013.7.7847.

13. Г. А. Пакерман. Опыт унификации права об инвестициях в Европейском союзе // Международное право и международные организации / International Law and International Organizations. - 2012. № 1. - С. 104-107.

14. О. А. Краснопёрова. Источники интеграционного налогового права как элемент налогового механизма государств-членов ЕС // Налоги и налогообложение. - 2012. - № 3. - С. 104-107.

15. Никиткова У.О.. Об эффективности практики местного налогообложения // Налоги и налогообложение. - 2013. - № 12. - С. 104-107. DOI: 10.7256/1812-8688.2013.12.10238.

16. Савина О.Н.. Региональная налоговая политика в условиях развития инновационной экономики: теоретический аспект // Налоги и налогообложение. - 2013. - № 12. - С. 104-107. DOI: 10.7256/1812-8688.2013.12.6489.

17. Башкирова Н.Н.. Этические основы возникновения налоговых рисков государства // Налоги и налогообложение. - 2013. - № 9. - С. 104-107. DOI: 10.7256/1812-8688.2013.9.9672.

18. В.А. Гидирим. Принцип резидентства корпораций в международном налоговом праве // Налоги и налогообложение. - 2013. - № 2. - C. 104-107. DOI: 10.7256/1812-8688.2013.02.3.

19. О. Н. Савина. Региональная налоговая политика в условиях развития инновационной экономики: теоретический аспект // Налоги и налогообложение. - 2012. - № 2. - С. 104-107.

20. О. И. Хайруллина. Налоговые аспекты амортизационной политики // Налоги и налогообложение. - 2012. - № 1. - С. 104-107.

21. А. В. Васильев. Цены, инфляция, налоги, инновационное развитие. // Политика и Общество. - 2011. - № 5

22. Некрасов А.И. Основы правового регулирования политики Европейского Союза в области финансовых услуг // Международное право и международные организации / International Law and International Organizations. - 2013. - 2. - C. 210 - 209. DOI: 10.7256/2226-6305.2013.2.6341.

23. В. Б. Рыжов Политика торговли и развития Европейского союза // Международное право и международные организации / International Law and International Organizations. - 2011. - 3. - С. 151 - 158.

\section{References (transliteration):}

1. Gidirim V.A. Printsip rezidentstva korporatsii v mezhdunarodnom nalogovom prave // NB: Mezhdunarodnoe pravo. -2013. - № 1.-S.123-170. DOI: 10.7256/2306-9899.2013.1.427. URL: http://e-notabene.ru/wl/article_427.html 
2. Postnikova E.V. Pravovoe regulirovanie priznaniya professional'nykh kvalifikatsii v sfere predostavleniya uslug v Evropeiskom Soyuze // NB: Mezhdunarodnoe pravo. - 2013. - № 1. - S.75-122. DOI: 10.7256/23069899.2013.1.592. URL: http://e-notabene.ru/wl/article_592.html

3. Babin B.V. Programmatic Regulation in the Modern International Law // NB: Mezhdunarodnoe pravo. 2013. - № 3. - S.1-35. DOI: 10.7256/2306-9899.2013.3.9302. URL: http://e-notabene.ru/wl/article_9302.html

4. A.V. Grishin. Evro kak natsional'naya valyuta tret'ikh stran i territorii s osobym statusom // Pravo i politika. - 2009. - № 8 .

5. O.V. Guseva. Evropeiskii Soyuz: pravovoe regulirovanie pryamykh inostrannykh investitsii. // Politika i Obshchestvo. - 2009. - № 6.

6. Inshakova A.O.. Unifitsirovannoe pravovoe pole innovatsionnogo ekonomicheskogo razvitiya i nanotekhnologii ES // Pravo i politika. - 2013. - № 7. - S. 104-107. DOI: 10.7256/1811-9018.2013.7.7847.

7. G. A. Pakerman. Opyt unifikatsii prava ob investitsiyakh v Evropeiskom soyuze // Mezhdunarodnoe pravo i mezhdunarodnye organizatsii / International Law and International Organizations. - 2012. № $1 .-$ S. 104-107.

8. O. A. Krasnoperova. Istochniki integratsionnogo nalogovogo prava kak element nalogovogo mekhanizma gosudarstv-chlenov ES // Nalogi i nalogooblozhenie. - 2012. - № 3. - S. 104-107.

9. Nikitkova U.O.. Ob effektivnosti praktiki mestnogo nalogooblozheniya // Nalogi i nalogooblozhenie. - 2013. - № 12. - S. 104-107. DOI: 10.7256/1812-8688.2013.12.10238.

10. Savina O.N.. Regional'naya nalogovaya politika v usloviyakh razvitiya innovatsionnoi ekonomiki: teoreticheskii aspekt // Nalogi i nalogooblozhenie. - 2013. - № 12. - S. 104-107. DOI: 10.7256/1812-8688.2013.12.6489.

11. Bashkirova N.N.. Eticheskie osnovy vozniknoveniya nalogovykh riskov gosudarstva // Nalogi i nalogooblozhenie. - 2013. - № 9. - S. 104-107. DOI: 10.7256/1812-8688.2013.9.9672.

12. V.A. Gidirim. Printsip rezidentstva korporatsii v mezhdunarodnom nalogovom prave // Nalogi i nalogooblozhenie. - 2013. - № 2. - S. 104-107. DOI: 10.7256/1812-8688.2013.02.3.

13. O. N. Savina. Regional'naya nalogovaya politika v usloviyakh razvitiya innovatsionnoi ekonomiki: teoreticheskii aspekt // Nalogi i nalogooblozhenie. - 2012. - № 2. - S. 104-107.

14. O. I. Khairullina. Nalogovye aspekty amortizatsionnoi politiki // Nalogi i nalogooblozhenie. - 2012. - № 1. - S. 104-107.

15. A. V. Vasil'ev. Tseny, inflyatsiya, nalogi, innovatsionnoe razvitie. // Politika i Obshchestvo. - 2011. - № 5

16. Nekrasov A.I. Osnovy pravovogo regulirovaniya politiki Evropeiskogo Soyuza v oblasti finansovykh uslug // Mezhdunarodnoe pravo i mezhdunarodnye organizatsii / International Law and International Organizations. - 2013. - 2. - C. 210 - 209. DOI: 10.7256/2226-6305.2013.2.6341.

17. V. B. Ryzhov Politika torgovli i razvitiya Evropeiskogo soyuza// Mezhdunarodnoe pravo i mezhdunarodnye organizatsii / International Law and International Organizations. - 2011. - 3. - C. 151 - 158. 